\title{
Correction to: Effects of short-term exposure to ambient airborne pollutants on COPD-related mortality among the elderly residents of Chengdu city in Southwest China
}

\author{
Jianyu Chen ${ }^{*}$, Chunli Shi, Yang Li, Hongzhen Ni, Jie Zeng, Rong Lu and Li Zhang*
}

\section{Correction to: Environ Health Prev Med (2021) 26:7 \\ https://doi.org/10.1186/s12199-020-00925-x}

Following publication of the original article [1], the authors noticed that only one corresponding author was published online. In the submitted manuscript, there are two corresponding authors, Jianyu Chen and Li Zhang, but only Jianyu Chen was reserved in the published version.

The original article [1] has been updated.

Published online: 16 February 2021

\section{Reference}

1. Chen J, Shi C, Li Y, et al. Effects of short-term exposure to ambient airborne

pollutants on COPD-related mortality among the elderly residents of

Chengdu city in Southwest China. Environ Health Prev Med. 2021;26:7

https://doi.org/10.1186/s12199-020-00925-x.

The original article can be found online at https://doi.org/10.1186/s12199020-00925-x

*Correspondence: aculacjy@163.net; 657096242@qq.com

Sichuan Provincial Center for Disease Control and Prevention, No. 6

Zhongxue Road, Wuhou District, Chengdu 610041, People's Republic of

China

(c) The Author(s). 2021 Open Access This article is licensed under a Creative Commons Attribution 4.0 International License, which permits use, sharing, adaptation, distribution and reproduction in any medium or format, as long as you give appropriate credit to the original author(s) and the source, provide a link to the Creative Commons licence, and indicate if changes were made. The images or other third party material in this article are included in the article's Creative Commons licence, unless indicated otherwise in a credit line to the material. If material is not included in the article's Creative Commons licence and your intended use is not permitted by statutory regulation or exceeds the permitted use, you will need to obtain permission directly from the copyright holder. To view a copy of this licence, visit http://creativecommons.org/licenses/by/4.0/ The Creative Commons Public Domain Dedication waiver (http://creativecommons.org/publicdomain/zero/1.0/) applies to the data made available in this article, unless otherwise stated in a credit line to the data. 